IP Periodica Polytechnica Architecture

46(1), pp. 6-16, 2015

DOI: 10.3311/PPar.7851

Creative Commons Attribution (i)

RESEARCH ARTICLE

\section{Report about the Architectural Survey of the Parish Church of the Settlement of Chiddes}

\author{
László Daragó $^{1 *}$, Dániel Bakonyi ${ }^{2}$
}

Received 03 July 2014

\begin{abstract}
The partly medieval church of Chiddes in the South of Burgundy had been surveyed and researched in 2010 by students of architecture from the Budapest University of Technology and Economics. The survey was part of a 20-year long campaign by the French organization CEP (Centre International d'Etude des Patremoines Culturels) for the inventory of Romanesque churches and chapels in the Charolais-Brionnais region. The result of the survey and the research is introduced, and the findings are summed up in the form of a hypothetical relative periodization of the church.
\end{abstract}

\section{Keywords}

Romanesque ecclesiastic architecture, architectural survey, building archaeology, Chiddes

\section{A brief introduction of the architectural surveys in Southern Burgundy}

In the summer of 2010, students of architecture from the Budapest University of Technology and Economics, led by the authors took part in a survey and research campaign in the Charolais-Brionnais region of South Burgundy for the third time. The French partner organization, which has been running this programme of architectural surveys for the past 20 years, is a civilian initiative called CEP (Centre Internacional d'Etude des Patremoines Culturel). ${ }^{1}$ One of the two churches surveyed that year, the parish church of Chiddes, is presented here with the results of the measurements and the subsequent research by the authors.

\section{General description of the building}

The patron saint of the church of Chiddes is Saint-Etienne (St Stephen) celebrated on the $26^{\text {th }}$ December. The church itself consists of a single nave, a short single-nave transept with a larger rectangular crossing, and a semicircular apse that is connected to the crossing without a choir. A sacristy was added to the eastern end of the church, which has the same width as the apse.

From Romanesque times, the church has kept its crossing, the bell tower over it, the apse, a large portion of the northern

1 The CEP was founded in 1989 by a small community of local patriotic historians. During the last 20 years, the association has constantly expanded, and has made a significant contribution to the inventory and preservation of the historic monuments of Southern Burgundy, which belong to the World Heritage. The main line of their research focused on sacral monuments, first and foremost from the Romanesque period of the Charolais-Brionnais region. The exceptional density of more than 100 Romanesque or partly Romanesque churches and chapels grants a unique importance to this region. The CEP has been taking care of this heritage since its establishment. It also takes part in international programmes such as "Transromanica", conducted by the EU, which has gained the title of "Major Cultural Route" in 2007. This project aimed to connect these 100 sacral places around Cluny and Paray-le-Monial, and it attracts more than 200,000 registered visitors every year.

The campaign of 2010 involved the parish churches of Chiddes and Sanvignes-les-Mines. The survey was carried between the 25 th of July and the 12 th of August. The participating students were Barbara Csillik, Krisztina Fehér, Márton P. Kaszai, Zsuzsanna Kiss, Kornélia Losonczy and István Makai from Budapest and Manon Charvolin from Paris. 


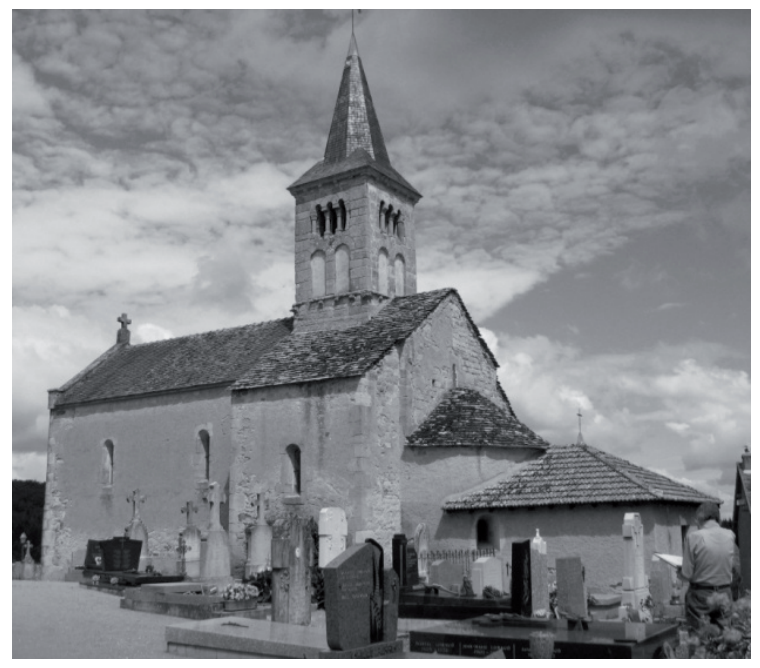

Fig. 1 The parish church of Chiddes

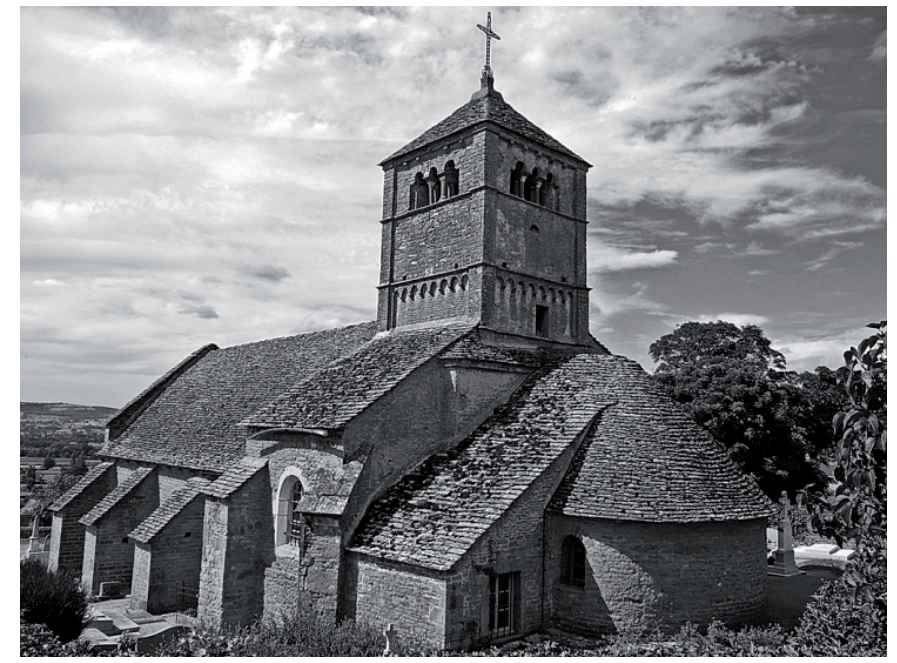

Fig. 2 The parish church of Ameugny transept and probably the foundation walls of the southern one. The nave and the visible parts of the southern transept are of later origin. The mass of the church is well proportioned, although it has a peculiar character: the size of the bell tower is smaller than the crossing, only its western wall is aligned with the western triumphal arch; the other walls are resting directly on the masonry structure of the vaulting. The tower has three levels. The bottom level is barely visible above the transept's roof; it lacks any openings (except a small one leading into the attic of the nave providing an access into the tower) and it is finished with a single stone row cornice supported by stone brackets. The middle part is decorated with two large false windows (very likely they have been filled-in sometimes after the Middle Ages) while the top part has triple coupled windows on all sides. The small semicircular arches are resting on small, double dwarf columns. Rameau described these windows as a downsized version of those that can be seen on the nearby church of Ameugny (Rameau, 1899). The crossing has different dimensions than the transepts, which are somewhat shorter in the longitudinal direction. This shift can be clearly seen on the plan, and it is also obvious if we observe the eastern walls of the crossing and the transepts: the former is slightly out-projected. The same out-projection can be seen on the western wall of the southern transept, but the symmetrical one at the northern transept has been later concealed by the newer upper walling. The width of the sanctuary, however, matches the width of the crossing exactly, so the jump in the wall is only visible above the sanctuary roof. The walls of the nave do not run along the lines of the crossing either, but we do not expect them to do so because of their later origins. The sacristy gives an odd character to the mass as it is situated east of the sanctuary in the longitudinal axis of the church, which covers the whole width of the apse at the lower parts.

Most of the outer walls are plastered except the tower and the west wall. There are four different kinds of roof-covering stone slabs on the crossing, the transepts and the apse, slating on the tower and two types of roof tiles over the nave and the sacristy. The western wall of the nave has an odd character as it turns inwards at the middle and forms a practically deep doorway. Most of the wall is half as thick as it seems to be, as the remaining hollow parts were walled up to form a store room and an access (ladder) leading into the attic. The interior is vaulted, but the nave has a lightweight wooden construction in the form of a ribbed cross vault with pointed (ogive) arches. The ribs are supported by cantilever stone elements. The crossing and the transepts are vaulted with a massive masonry structure; they have pointed-arch barrel vaults along the longitudinal direction over the crossing and along the transversal direction over the transepts. The vaulting of the apse is a usual semi dome, but the Triumphal Arch separating it from the crossing is a pointed arch, so the dome is not perfectly spherical.

\section{The history of the Church according to historic sources}

The settlement of Chiddes, or its ancient name Villa Chedias is mentioned several times in the charters of Cluny between 920 and 1020 (Bernard, 1876-1903). In 940, the Count of Nevers and his wife donated the village to the nearby monastery of Cluny. For centuries Chiddes was not an independent parish, it was under the patronage of the nearby village of Pressysous-Dondin (Rameau, 1899). There are no known written documents regarding the building date of the current church, but most historians put its origin somewhere in the middle of the $12^{\text {th }}$ century (Virey, 1899). There is no further mention of Chiddes until 1513, when it is once again described as the dependency of Pressy.

In 1675 , after an ecclesiastic visit, the church is described to be in a run-down state. In 1699, the archpriest of Mont-deFrance also visited the village and subsequently gave a description of the church. The apse and the crossing were painted while the nave was without any vaulting or even a wooden 
ceiling. He also mentioned two chapels, probably two altars in the northern and southern arms of the transept, one dedicated to Mary, the other to Saint-Laurent. (Oursel, 1934)

In 1746, after another pastoral visit, archpriest Rousset gives a thorough account of the church and its furnishings. The apse was in a bad condition, but it still had all of its three original windows. The semi-dome vaulting was cracked, and it was in danger of falling down. In the crossing, a huge ladder could be seen, which was used to reach the bell tower above and through a circular hole in the vaulting. The tower showed the same face as today, except that it was covered with a much smaller pyramid shaped roof covered with stone slabs. The nave was still without a ceiling, and the slightly decayed roof had a large deflection under the roof covering. Rousset only mentions a single entrance to the church: the large western gate in the nave (Visites pastorales de l'archiprêtré du Rousset, en 1746, 1913).

The 1812 survey (Fig. 2) shows a somewhat different state from what can be observed today. The nave seems to be somewhat shorter and the sacristy is missing - since it is a $20^{\text {th }}$ century addition. However, the most interesting part is the southern transept, which appears to be smaller than its present state with its south-western corner missing. Granted, this could be just the result of some inaccuracy of the survey, but it could also be interpreted as an evidence of a real structural deficiency. As we will see later, there are some other findings that support the latter hypothesis.

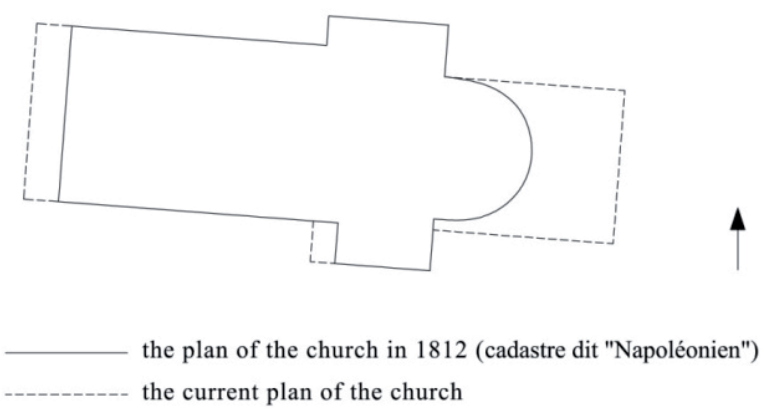

Fig. 3 Comparison of the $19^{\text {th }}$ century survey plan with the current one

Chiddes became an independent parish in 1789 for the first time, and an independent village in 1889 with 340 inhabitants (Rameau, 1899). According to town records, in 1861, the church had got into a critical state and a decision was made to urgently begin demolishing the ruinous parts and start reconstruction works. The work was controlled by the architect Jean Loron from Saint-André-le-Désert. The work was commissioned to Jean Machillet, an entrepreneur from Saint-Christophe, in 1863. The western gable of the northern transept as well as some exterior parts of the crossing and the apse (probably the exterior surfaces and upper parts) had to be demolished, the leaking roofs were repaired, and some windows and the entrance to the tower were enlarged. (Oursel, 1969)

\section{Survey method}

The surveys methods used by the authors for these campaigns in Southern Burgundy were introduced in a previous article in greater detail; therefore only a very limited description is given here and the reader is referred to that earlier work (Daragó, Bakonyi, 2011). This method follows the principles of "building archaeology" as far as the limited period of time allowed it. This work tends to be a part of different surveys carried out by the Building Archaeology Workshop of the Department of History of Architecture and of Monuments in the Budapest University of Technology and Economics. We believe that this survey provides principle data for research, and the drawings are not just for illustrating the outcome of historic research as declared in an article about the survey of the Baroque Marionette Theatre in Eszterháza (Hungary) (Krähling et al., 2006).

The character of the survey was exactly between an architectural measuring of $M=1: 50$ scale and a detailed true-toform building archaeology survey of $M=1: 20$. No coordinate system was fixed directly onto the building and the final drawings were drawn off site, but in the "in-situ" drawings we attempted to document every wall texture and structural or material detail to the extent that was possible in the short amount of time available to us.

The measurements were carried out partly by hand and partly (mainly) with an electronic total station. A mixed method using the in-situ drawings and hand measurements, photogrammetry and the digital measurements allowed us to reconstruct the exact spatial geometry of the church in great detail and precision. These drawings provide valuable data for the historical and structural composition of the building and can provide a firm basis for further survey.

\section{General observations}

Even without a detailed archaeological survey, there are several aspects of the building that can be investigated to try to establish a hypothetical periodization of the different constructional parts. The analysis of the constructional grids, wall thicknesses, wall movements, wall textures and materials, the windows, gates and other details can all provide valuable information.

\subsection{Constructional grids}

Analysing the orientation of the different parts of the church for the first time, one may be tempted to conclude that it is best described by a single grid-system. The longitudinal axis of this grid is staked out by the centre-point of the apse and the centre-point of the crossing. This grid also fits the apse, the northern transept, the eastern wall of the southern transept, the entire nave and with some tolerance: the sacristy. The interior surface of the eastern wall of the southern transept shows some deviation from the direction of this grid but only near the floor. This may be caused by a slight increase in the wall thickness or 


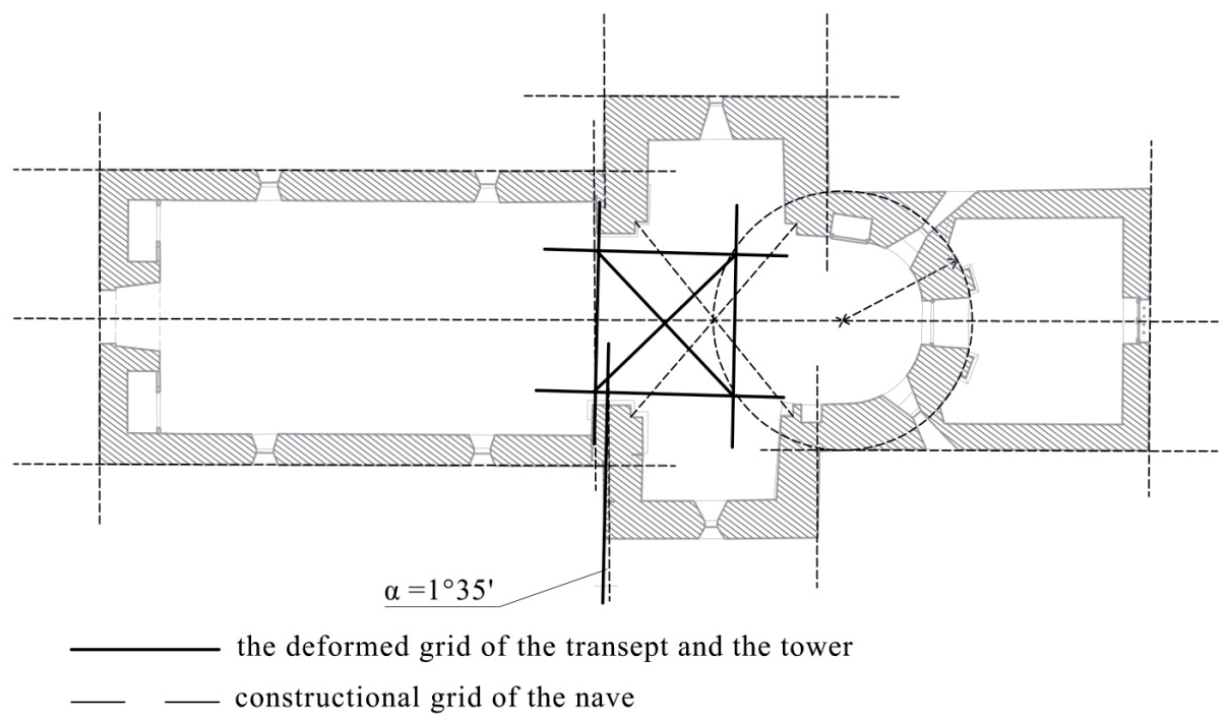

Fig. 4 The constructional grids of the church

the plastering as a result of some correctional restorations. At any rate, this irregularity is so small that we cannot draw any far-reaching conclusions on this basis.

However, there are some parts that break this rule and can be regarded as following a slightly different system. This "deformed" grid seems to be twisted clockwise from the general grid. The western wall of the south transept and all parts of the tower belong to this deformed system. The deviation seems to increase towards the south-western corner of the transept where it reaches a maximum of $1^{\circ} 35^{\prime}$ from the original grid. Almost no perfectly parallel or perpendicular lines can be observed here, except for those parts mentioned earlier that fit to the main system.

It is confusing that there are elements belonging to the same structure (e.g. the transept or the crossing) but defined by different grids. This can either be the result of poor quality workmanship by the medieval masons (an inexact staking out), or the deformation of the construction in later times. The nature of these deviations is unlikely to be a result of only an inaccurate staking out as they are much too large for that, especially if we consider the accuracy of the rest of the medieval parts. The overlapping of the centre of the crossing with the chief grid of the non-deformed parts of the church indicates that the main grid was the original system used by the builders in the earliest building period, but subsequent deformation and perhaps reconstructions of certain parts departed from the original geometry. The key to answering the question of the grids is to analyse them together with the structures, the wall textures and the possible constructional periods and see whether we can find believable explanations that fit all of the findings.

\subsection{Wall thicknesses}

According to the wall thicknesses six different groups can be identified (see Fig. 4):

a) The thickest wall surrounds the western gate of the nave with $118 \mathrm{~cm}$. The rest of this wall is much thinner, so as this part of the church is clearly of 19th century origin, presumably from the 1863 reconstruction works; the huge thickness of the gate appears to be just an architectural trick to simulate a medieval construction. There are also some indications in town records that, in the 19th century, the village considered demolishing the damaged bell tower and building a much smaller bell wall above the western entrance, so this thick wall might have served as a support for this construction, although they clearly abandoned the idea. If this account is true, this would have been a particularly unusual construction for the region, even in the $19^{\text {th }}$ century as the customary position of bell-walls since Romanesque times was over the western wall of the crossing, like in Saint-Martin-deLixy. Fortunately the bell tower was preserved, and this thick wall does not continue above the vaulting.

b) The four pillars of the crossing of around one metre are the thickest constructions of the church's old parts. The larger dimensions of these pillars compared to the transept wall can be observed from the outside just under the roof. The pillars are almost always thicker than the ordinary walls; the reason can either be a natural tectonic aspect or a technological one. If we think of the pillars of the crossing as a skeleton construction, our natural sense of tectonic experiences force us to enlarge its structural profile, comparing it to a continuous wall. From a technological viewpoint, the "legs" of the crossing are made of ashlars on at least two sides; this may result in a somewhat different dimension than in the case of a wall made of irregular stones.

c) The walls of the northern transept, the apse, the eastern wall of the southern transept and the eastern gable wall of the crossing above the arch between the crossing and the apse, all measure 80 to $90 \mathrm{~cm}$ in thickness. A true approximate three feet thick wall typical of Romanesque times. Sometimes we find a somewhat thinner wall in the apse, but in most cases these thinner curved walls are bearing false arcades on the inner side, and their overall dimension of the whole construction is approximately three feet thick like in the case of the parish-churches of 


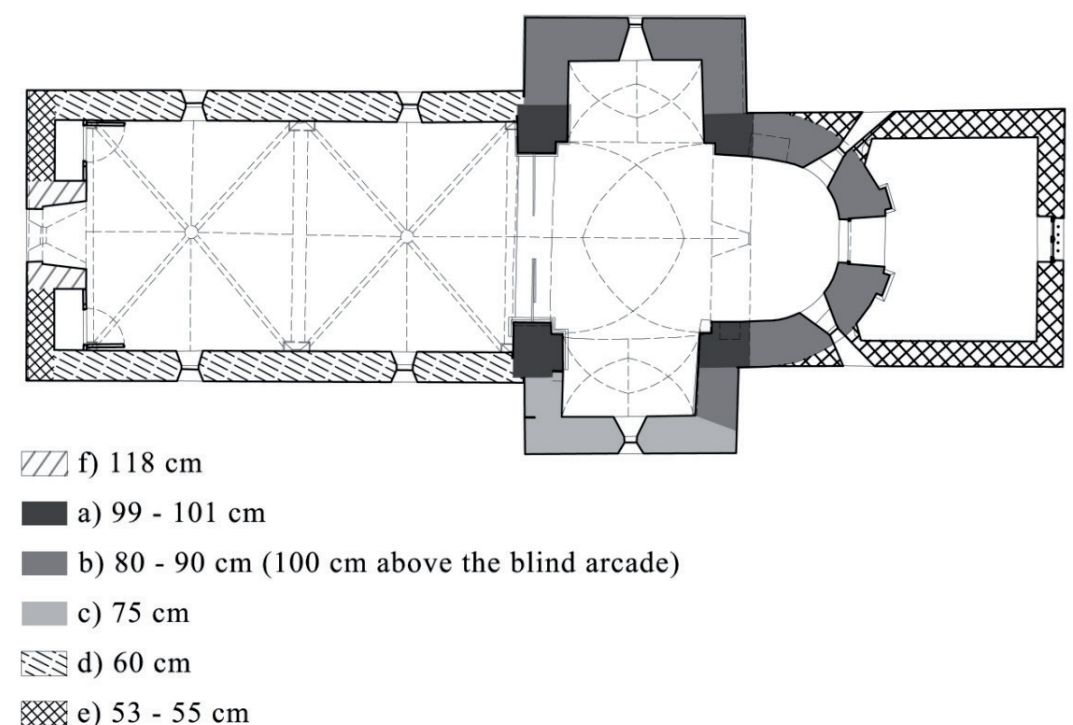

Fig. 5 The different wall thicknesses

Sanvignes, Baron or Champlecy. Here, the apse has no articulation, so the thickness is evenly three feet all around the chancel.

d) The southern and western walls of the southern transept are $75 \mathrm{~cm}$ thick, noticeably thinner than the walls in group c), the difference being too large compared to the three feet medieval custom to put them in the same group. This is most interesting when we remember that the 1812 survey plan shows a different floor plan in precisely this part of the church. Furthermore, as we saw earlier, the southern and western walls of the transept also have a different constructional grid from their surroundings. All this strongly indicates that these two walls are of later origin and significant building works were carried out in this part of the church.

e) The two longitudinal walls of the nave are $60 \mathrm{~cm}$ thick, considerably weaker than the old parts. The bell tower over the crossing has also the same thickness, but this does not reflect upon its age as bell towers were always built as light as seemed possible to prevent them from putting too large a load on the system of vaultings and arches below.

f) The thinnest walls are of the sacristy and the western façade of the nave except for the gate and its immediate surroundings. These walls are only 53-55 cm thick. In the case of the nave, this indicates that the western façade may be from a different building period than its longitudinal companions. This is also supported by the 1812 survey plans where the church is depicted somewhat shorter in the western direction. Perhaps the current western façade built in the 19th century was erected further to the west than the previous one.

\subsection{The tilting of the walls}

On first sight, most of the walls of the church seem to be perfectly vertical, but on closer inspection, some fairly significant structural movement can be observed: the whole of the crossing with the bell tower on top and the southern arm of the transept are leaning in a south-west direction. These deformations are both observable in the floor plan of these parts - as seen earlier - and the tilting and deformations of the walls and vaults. The triumphal arch between the nave and the crossing is leaning $6 \mathrm{~cm}$ to the west perpendicular to its plane, while its keystone has moved $9 \mathrm{~cm}$ and its southern impost almost $14 \mathrm{~cm}$ to the south from its original position. The deformations of the arch between the crossing and the apse are somewhat smaller, with its keystone moving $7 \mathrm{~cm}$ and its impost only $5 \mathrm{~cm}$ to the south. The longitudinal facing pointed-arch barrel vault above the crossing is also heavily deformed: its southern support, the southern arch of the crossing has moved $16 \mathrm{~cm}$ to the south which is quite significant for a construction only $4.5 \mathrm{~m}$ tall. The south-east pillar of the crossing is also tilting $6 \mathrm{~cm}$ in the same direction. In this part of the church, only the southern and western walls of the southern transept are vertical, which also underlines their later origin.

The centre of the crossing remained the same, but the whole of the bell tower has moved more than $6 \mathrm{~cm}$ to the south-west. It is also leaning slightly to that direction, and as we saw earlier it has twisted in a clockwise direction (towards south-west). The question is: what was the cause of all these deformations?

The bell tower of the church is quite a bit smaller than the crossing on which it rests, therefore, only its western wall is supported directly by the western arch of the crossing, the rest is sitting on the pointed-arch barrel vault over the crossing itself. This produces large horizontal forces in this vault, which are in turn supported by the transversal barrel vaults and walls of the transepts. However, all indications show that some serious structural failure took place in the south-western corner of the crossing, the vaulting system lost its support, and the huge weight of the crossing started to push the southern supports in that direction while the northern and eastern supports remained intact. Why the south-west corner has failed is not entirely sure, 


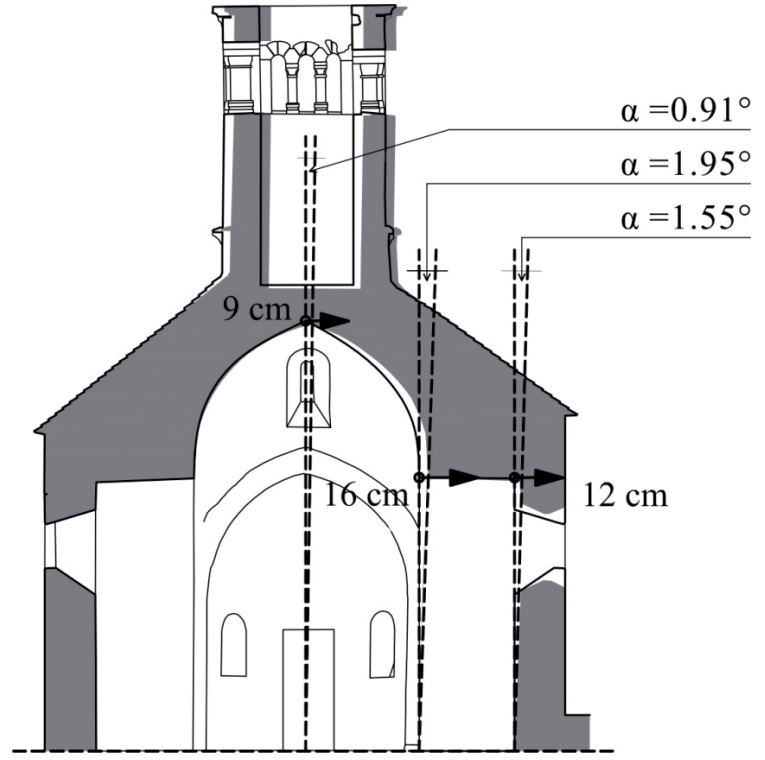

Fig. 6 Comparison of the current cross section with its hypothetical original undeformed state

but there is a case to be made that it might have been because of foundation problems. The church itself is located on top of a small hill with the village cemetery located to its south and west, as was the custom in the area. Even now, the graves are less than a meter away from the walls. Any combination of loosened soil, surface water not properly lead away but absorbed by the ground and insufficiently deep foundation levels could have resulted in foundation failure. Without a geotechnical survey, it is hard to speculate further.

When these movements took place cannot be exactly determined, but the church was described in texts as being in a ruinous state in 1675 and then again in 1746 (see in Oursel, 1969 and Rameau, 1899). As previously mentioned, the 1812 survey also depicts a possible damaged south-west corner; therefore, the current southern and western walls of the transept could originate from the $19^{\text {th }}$ century (sometime after the survey). Since these two walls have remained vertical since then, the movements must have stopped; although, there are some recent cracks in the vaulting of the crossing near the crown, above the arch, between the crossing and the apse and the eastern wall of the southern transept.

The semi dome of the apse also shows cracks above the windows in the lower parts of the vault. These are not unexpected in case of such a construction, but they could also be related to the failure of the southern supports. The southern crack penetrates the whole width of the masonry and should be examined.

\subsection{The analysis of the wall textures}

Almost all of the outer surfaces of the walls are plastered; except the western wall of the nave, the northern wall of the north transept and some smaller parts of its other walls, the belfry and the eastern gabled wall of the crossing. On the rest of the walls, only the corner ashlars are exposed; there are some smaller "patches" where the plastering has been damaged and lost, as in the case of the longitudinal walls of the nave, along the height of the footing.

The Western wall of the nave is a typical $19^{\text {th }}$ century structure; probably constructed on the course of the last reconstructions in 1863 or even later (maybe after the village became an independent community in 1899), as the report about it did not mention the rebuilding of the western wall. It is made of finely cut ashlars. The lower level has larger rows than the somewhat recessed upper level, which has the same size large corner ashlars but smaller rows in between. Four rows under the gable, the stone measurements are decreased again, even at the corners. The openings have a typical $19^{\text {th }}$ century profile imitating medieval forms. The doorway is symmetrical, perfectly fitting into the wall-pattern and the wall-textures on both sides are keeping the same rows. The upper recessed level has some disturbances: on the two sides of the window, there are different levels for the rows, but they are perfectly aligned with the stone elements of the window-jambs, so they were still most likely walled together, and the jambs guided the arrangement. The gable has no such asymmetrical arrangement on the two sides of the upmost window letting light into the attic. There is a different texture unfolding: again smaller stones, more irregular than below, and the rows are not as even as the lower ones. There is a very simple stone cross on the top of the gable, very geometrical, without any kind of decoration. This simplicity suggests even a $20^{\text {th }}$ Century origin just as the window situated at the upmost position in the gable.

There is significant cracking on the southern wall of the nave indicating a probable border of two different structures belonging to two different periods. As the site-plan of the Napoleonic cadastre (1812) shows a shorter nave, we can assume that the western wall is a later addition, and as the last large known intervention happened in 1863 , we can accept it as the most probable date of the reconstruction of the whole western wall. However, the reason for the crack could also be the different rigidity of the structures, as in the line of the crack there are partition walls supporting the total height of the longitudinal walls.

The walls of the Northern transept can also be closely investigated as their masonry is exposed. The north wall of the transept has quite a different character from the western elevation of the nave. Only the corner stones are bigger ashlars; the wallstructure between them is made out of irregular stone rows with irregular elements. This is a typical medieval masonry: roughly cut (irregular but oblong form) stone elements forming levelled rows, sometimes subdivided, sometimes adjusted to corner ashlars with vertical measurements all different, and sometimes randomly changing their height on their own.

Unfortunately, we do not have an exhaustive survey of textures and structures of accurately dated Romanesque masonries from the region, but we can perhaps compare our findings with work already done elsewhere in Europe, like the wall typology of Prof. D. Fiorani (Fiorani, 1996). As we could only see the 
outside face of the unplastered walls, we have to rely on the exterior textures to make our comparisons; despite this, the previously referred to wall of Chiddes is quite similar to "class A4 group II $a$ " in Fiorani's catalogue. According to the window forms we can date our walls back to the late $12^{\text {th }}$ or the early $13^{\text {th }}$ century. In Lazio, this wall type appears rarely in the $11^{\text {th }}$ Century, more frequently in the $12^{\text {th }}$ Century and is still present in the $13^{\text {th }}$ Century. We do not want to suggest that the two regions had certain cultural connections at that time, we rather presume that the building technology developed in parallel in different parts of Europe. On the basis of this idea, we can presuppose a kind of "sensus commensis" in these times in architecture, meaning that similar problems involved similar solutions.

At the third stone row above the window there is a horizontal separation, a difference in texture and material. Some of the corner ashlars are missing or were substituted by smaller irregular stones. The vertical rhythm of the corner stones also changes at this upper section: the even "1-2-1-2" sequence (same size ashlars one in a row topped by two in the other row) turns to an uneven "0-1-1-1" (different size ashlars topper by single elements). The lower, older parts are made of bluish grey sandstone, whereas the upper parts are made of yellowish stone. This all dates this upper part to a later reconstruction. With the help of historical sources, we can perhaps date this to the 1863 reconstruction works (Oursel, 1969).

The size of the medieval ashlars is not constant. At the eastern edge of this northern wall, above the level of the shoulder of the window, the ashlars are smaller. This change does not mean anything as we can also find two pairs of similar size stones, set into a range of larger ones, on the other side. So we can state that the occurrence of smaller ashlar stone is occasional. The connection of the ashlars and the intermediate wall texture is very characteristic. The intermediate stone rows are not perfectly adjusted to the ashlars. The same imperfections can be observed at the window jambs. These can be explained in two ways: they were either built in different periods, or the quality of the craftsmanship was poor. We think that the latter explanation is the case as these imperfections occur only occasionally, and we can find such kind of level differences all over the wall surface. So this can be regarded as the "fingerprint" of the master builders who worked here, and it tells the story of how they attempted to solve the problem to adjust the levels of the rows resulting from the different-sized corner ashlars on the two ends of the same wall. Moreover, the stone rows on the two sides of the window are not running in the same level; sometimes on the level of the same ashlar there are two stonerows on the western side, whereas there are three rows on the eastern side. This excludes the later embedding of the window into the wall. So this asymmetry also confirms the same origin of the elements of the north wall of the transept.

The imprints of this later reconstruction can be detected on the eastern elevation of the Northern transept around the corner. Though the corner ashlars remained untouched, the higher parts - the gable of the crossing are different: the stones are yellow and smaller than the medieval ones, and their size is more regular. The connection of the corner ashlars and the intermediate wall-texture shows the same "fingerprints" that we could see on the northern side.

We can be sure that the Eastern-wall of the crossing is of medieval origin up to the shoulder of the gable window because of the scaffolding-holes. Alternatively, we can regard the whole gable as medieval in view of the imperfections and the unlevelled rows. The dissymmetry of the wall-texture on the two sides of the window (and also on the two sides of the triumphal arch hidden by the sanctuary) also confirms this. However, there is a visible change in the pattern above the level of the scaffolding holes. The ashlars at both edges of the eastern gable are smaller stones: they are of the same size as the average stones inside the texture, whereas, lower down (the original medieval parts), the ashlars are twice as large as the average ones. The stones of the wall are also quite even in size, and somewhat smaller at the lower part. Their colour is lighter, yellowish, but this may be caused by the plastering -recently fallen off- that covered and protected these surfaces for a certain length of time. The rows are disturbed. They wind up and down and sometimes they are even discontinuous. Almost all of the horizontal joints above the window are bent upwards with no levelling row. So these disturbed parts belong to a different period. The upper corner of the left "jamb-stone" of the upper right scaffolding hole is carved off to provide space for the "lintel-stone". This only makes sense if the lintel still belongs to the same period; therefore, the border between the two constructional periods is somewhere above the lintel. We can fix the lower parts as medieval textures, but the upper parts were rebuilt in a later reconstruction.

It is also important to remark that the rhythm of the corner ashlars of the eastern-crossing wall - at both ends - is not identical to the one of the northern transept. Whereas the Northern transept is edged with the alternating rhythm of 1-2-1-2-1-2, the crossing-wall has a simple rhythm of 1-1-1-1. However, the difference in texture does not mean a difference in the date of construction. As a matter of fact, the two ends of the eastern crossing-wall differ from each other: the measurements of the ashlars are different. We regard these differences as a natural character of provincial medieval texture. The medieval origin of the eastern crossing-wall is very probable as the whole crossing with its vaultings and also the whole body of the tower is resting on it. The only structural gap - real cracking - can be seen between the ashlars of both edges of the wall and the intermediate wall texture. However, these gaps do not sign a border between periods of construction either; to the contrary, they confirm their correspondence. We have to refer to our previous observations regarding the displacement of the shoulders of the crossing arches: we measured $16 \mathrm{~cm}$ displacement outwards at shoulder level meaning that the lower parts of the 




Fig. 7 The remnant of the southern doorway in the southern transept (as seen from the interior) and the theoretical reconstruction of the original form

Eastern-crossing wall were enlarged. This tore the wall, and the cracks appeared at the border of walls of differing rigidity. Similar cracks (larger vertical joints between stones above each other) can be seen beside both sides of the window, though they are hardly noticeable because of patches of plastering on the surface. These visible displacements show the inhesion of the crossing and the wall above its Eastern arch; it also fixes them to the time of deformation.

There is a significant difference between the ashlars of the medieval parts (Easter crossing-wall and the lower walls of the Northern transept) and the corner ashlars of the Southern transept. These stones are not so weathered; their edges are sharper and lighter in colour (at some places cool white) while their measurements vary widely - more so than in case of the medieval corner-ashlars. We could also find typical bush-hammered surface treatment originating from the $19^{\text {th }}$ Century. The intermediate wall surface is almost entirely covered by plastering, so is very difficult to study. At the upper part - at the junction of the crossing-wall and the Eastern wall of the Southern transept - there are some exposed patches: from here we could discern that these walls are masoned together as the stone rows are continued on both surfaces. This could sign the correspondence of the two walls. It is possible that ashlars were only substituted later. For a larger intervention we would need further clues; as a matter of fact there is a quite thick vertical joint visible, filled with mortar and some debris of stone, but we could not follow its path under the plastering. Despite this, we think that the corner ashlars of the Southern transept and some parts of the Eastern wall belong to a later period of construction, maybe a $19^{\text {th }}$ Century phase.

The Southern wall of the Southern transept is almost entirely covered, only the corner ashlars and the window-jambs, the lintel and the sill are exposed. The character of the corners is identical; the same sharp edges, the same sizes, the same colours. We cannot see the intermediate wall texture neither on the Southern side nor on the Western one. Fortunately there is a blinded opening on the latter side. It is a rather low former doorway with a straight lintel. As the jamb-stones and the lintel are interwoven with the corner ashlars, we can say that these walls belong to each other. This Western wall of the Northern transept does not align with the Western wall of the crossing: the outer (Western) face of the Transept wall is to the east regarding the corresponding one of the crossing-wall. We can see this recess over the roof. This is not symmetrical with the Northern side where there is no such recess. This "jump" of the wall-face on the Southern side is an anomaly. Moreover, this wall (Western wall of the Southern transept) has another imprint from the past on its interior surface. There are some archivolt stones remaining from a preceding period. If we reconstruct the original vaulting of this door, it proves to be a pointed arch. If we imagine this doorway, the present Southern wall does not fit to it as the wall meets the opening. To determine the original position of the longitudinal Southern wall of the nave, we can draw its inner side from the point where the footing of the South-west pillar of the crossing ends (it does not run as far as the corner, the present inner face of the present wall); and we can fix the outer surface from the point where the recess of the transept wall is situated.

The tower is slender: its horizontal dimensions are much smaller than the measurements of the crossing. Only its western wall is positioned on the top of the western triumphal arch - all the other walls are supported by the vaults of the crossing. Maybe for this reason the construction is rather lightweight. There are large coupled-windows on two levels: the lower ones are double-windows with pillars; the upper ones are triplewindows with dwarf-columns although their total widths are the same. The real load bearing structure looks like a skeletonstructure with four legs - the four pillars of the corners. Like a two-storey tetrapylon. The openings of the lower level were blinded later with thinner walls. There is an intermediate cornice at the still level of the lower, blinded, windows. It must have had a simple profile - but it became unrecognizable. The cornice is supported by corbels - in a very weathered status that are also typical for this region with a single concave curvature. The small patch of wall seen above the roof but under this cornice has a somewhat different texture compared to the upper parts. The dimensions of the tower at the level of the windows are $4-5 \mathrm{~cm}$ smaller than below the cornice. The walling type is similar to the northern and eastern side of the transept: the stone blocks are roughly cut to an oblong shape to create winding stone rows, but without ashlar reinforced corners.

The wall above the cornice has an even character. There are finely cut ashlars in diverse sizes, and the stone rows are not aligned with each other on the four corner pillars. There are two levelled horizontal joints that coordinate all corners: the shoulder of the lower windows and the rows above the extrados of the upper windows. From this, we can state, that the lower coupled windows were walled together with the corner pillars, whereas the upper windows (the four dwarf-columns and the three small 
arches above them on all the four sides of the tower) were made separately from them. Possibly only as a result of the technological sequence, and we cannot state that the triple-windows were made in a later building period. This is likely confirmed by the fact that on the eastern elevation at the northern and the southern pillar and the northern elevation at the western pillar (3 of the 8 shoulders), the shoulder-stone of the small archivolt is resting on the stones of the pillars. However, we cannot exclude the later inserting of these tripled windows into the wall. The footing and the abacus of the intermediate dwarf columns differ from the ones at the sides (placed into the corner-recesses of the pillars). Their subdivision and proportions, current weathered status, and the articulation of the capitals are all different.

The coronating cornice of the tower has a "syma" profile and has corbels similar to the ones at the lower cornice. The carved stones have so well preserved, sharp edges that their origin cannot be much more recent than the 19th century.

Unfortunately, the interior is almost completely plastered. The only exception is the bottom 1 meter of the nave's northern wall. Here, we can see small, completely irregular and very rudely carved stones. This differs starkly from the much more refined masonry works of the eastern parts. Despite the plaster and the painting, we can make out the contours of the large stones of the crossing pillars and the arches. These are sizeable and very finely cut ashlars.

\subsection{The analysis of the windows and other details}

The church in not rich in details, so we were only able to make a few observations regarding the building forms. The northern window of the transept, the eastern window of the crossing and the remaining two windows of the apse (from the interior) have a typical medieval size and shape typical of the $12^{\text {th }}$ and $13^{\text {th }}$ century. They are smallish, narrow and slender in proportion, the reveal is strongly tapered and their narrowest point is at the exterior surface.

The rest of the fenestration is completely different. According to sources, the window of the southern transept was enlarged in the $19^{\text {th }}$ century to mimic those on the nave. They are all significantly larger, with a tapering reveal from both sides and the narrowest point located in the outer third of the masonry. The western bottom window of the nave is built in a similar fashion while the gable window illuminating the attic has a much smaller and simpler design. The main western gate has no remarkable features either.

The most interesting details visible in the interior are the footing stones of the triumphal arch in the nave. Both of them are clearly of medieval origin, but they abruptly stop far short of the nave's walls. Either the rest were destroyed, or the original medieval nave was simply that much narrower than what we can see today. The footings of the sanctuary's buttresses were also preserved, and they are currently visible inside the sacristy. They have a very simple geometrical form with a plain tilted top.
The only worthwhile sculptural elements are the double dwarf columns in the top storey of the belfry. The abacus, the barrels, the capitals and the footing are made out of one-one single piece of limestone. The shapes are severely weathered and very provincial, representative of the $12^{\text {th }}$ century period in the region. The style of the capitals situated in the bell tower follow the Clunyac models. The archaic "sedge leafe" type originating from the Cluny II, $10^{\text {th }}$ century period (but also known in Dijon Saint-Begnin, and in Tournus Saint-Philibert in the $11^{\text {th }}$ century) is the source of this spreading detail. The $12^{\text {th }}$ century descendants of this type are well known in this region either around Toulon-sur-Arroux (capial No. 45 and 47) (Reiche, 2002) and around Mont-Saint-Vincent (16 pieces of this type have been measured). The interesting remnants of a row of "bubbles" along the main vein of the diagonal leafs has no relative detected in this region, so it can be a special local character.

\section{Summary of conclusions and a hypothetical relative periodization of the building}

The described observations and investigations enabled us to create a hypothetical periodization of the different constructional parts of the church of Chiddes. Figs. 8, 9, 10 and 11 illustrate these findings.

Period 1) The oldest parts of the church are without doubt the pillars and vaultings of the crossing, the tower (although perhaps built in two periods close to each other), the whole of the northern transept up to the level of the vaulting, the eastern wall of the southern transept and the apse. There must have been an original nave dating to this period that was later demolished for some reason. Based on our findings, we can venture a hypothetical reconstruction of this original state: Fig. 11. The jump in the western wall of the crossing, the original footing of the western pillars of the crossing and the mysterious western gate of the southern transept all indicate geometrically that the nave must have been somewhat narrower than today, although not by much. In all likelihood, it was unvaulted since virtually no churches of the same size in the region in the $12^{\text {th }}$ century had vaulted naves.

Period 2) Due to some damage (probably foundation problems), the south-western corner of the church had to be at least partially rebuilt. The southern and western walls of the southern transept may both have originated from this period. The western gate of the transept was preserved in this period as its new lintel stone is visible from the outside. The date of this intervention cannot be determined exactly, but it appears to have happened sometime before the $19^{\text {th }}$ century, perhaps even in baroque times.

Rousset, in his description of the church in 1764, (Visites pastorales de l'archiprêtré du Rousset, en 1746, 1913) only mentions a single western gate and a decayed roof above the nave, so the strange western gate of the transept must have been closed before this date.

Period 3) The old nave was demolished and replaced with a new slightly bigger one. The reason for this intervention is 


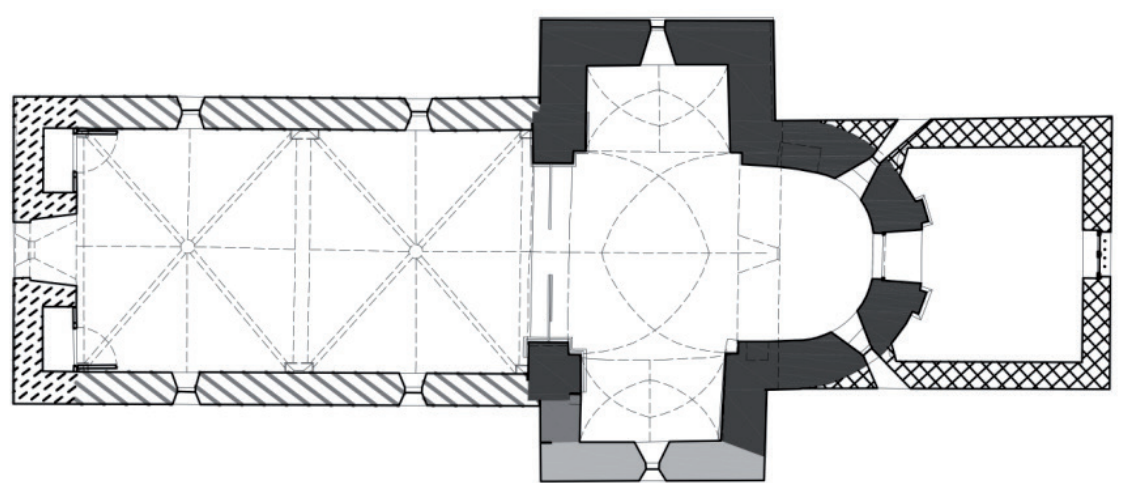

period 1) original building period

the walling up of the transept gate

period 2) southern an western walls of the southern transept

$\$$ period 3) new nave

[:i:; period 4) 1968 reconstructions and

xeriod 5) sacristy

Fig. 8 Hypothetical periodization of the church of Chiddes, ground plan

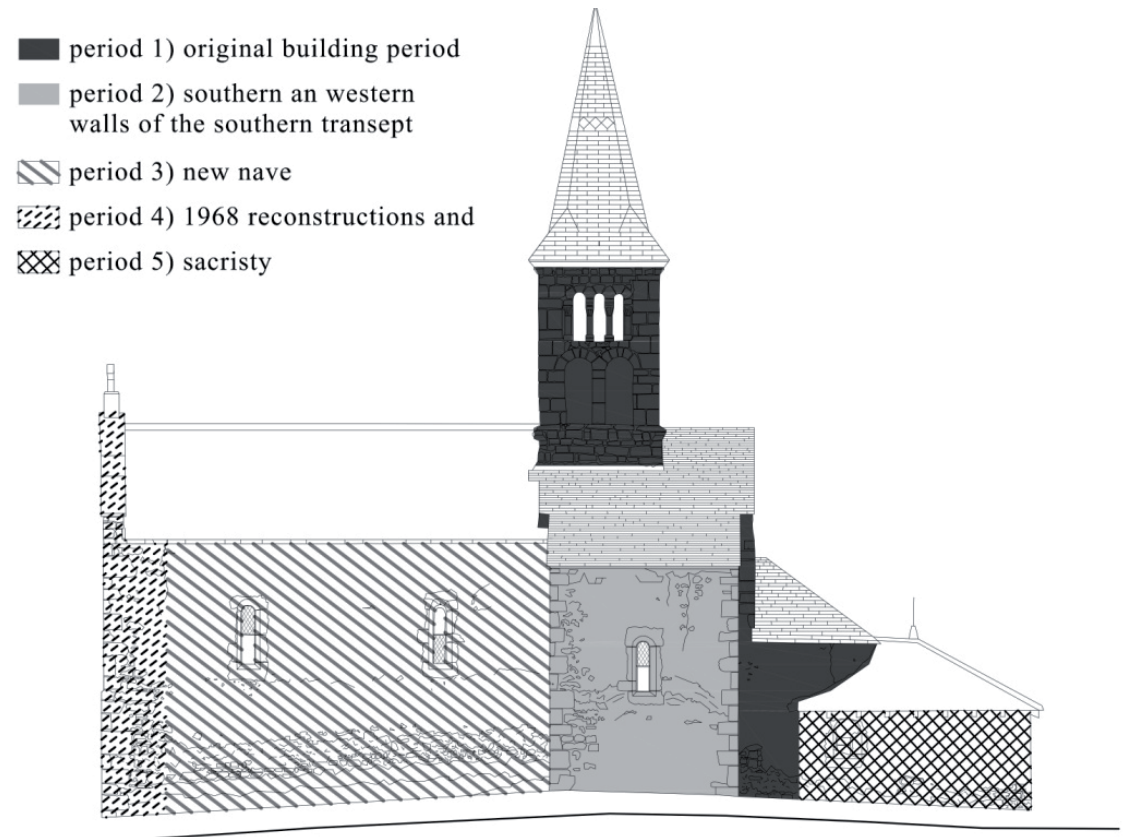

Fig. 9 Hypothetical periodization of the church of Chiddes, southern façade

unclear, most likely it was either due to some damage or it simply became too small for the community. The transformation of naves was commonplace in the region in the $19^{\text {th }}$ century.

Period 4) As the village records reveal some urgent works had to be carried out in 1863: the gable walls of the transept and much of the cornices had to be repaired or rebuilt due to moisture damage. Some of the windows were enlarged. It is most likely that the current western façade was also built in this period by demolishing the old one and slightly enlarging the nave. Records show that the tower was also in a critical condition, but luckily it was preserved and repaired, receiving a new roof.

Period 5) A sacristy was added to the eastern end of the church either at the very end of the $19^{\text {th }}$ century or the beginning of the $20^{\text {th }}$ century. The eastern central window of the apse was demolished to give way for a new door to the sacristy. 


\section{References}

Bernard, A. (1876-1903) Recueil des chartes de l'abbaye de Cluny, formé par Auguste Bernard complété, révisé et publié par Alexandre Bruel (Collection de documents inédits sur l'histoire de France - Première série. Histoire politique) 6 vol., Paris 1876-1903, réimp. Frankfurt/Main, 1974, BB 1439, BB 1575 and BB 1657 (in French)

Daragó, L., Bakonyi, D. (2011) Report about the Architectural Survey of the Parish Church of the Settlement of Sanvignes-les-Mines. Periodica Polytechnica Architecture. 42 (1). pp. 1-13. DOI: 10.3311/pp.ar.2011-1.02

Fiorani, D. (1996) Tecniche costruttive murarie medievali: il Lazio meridionale. Roma : L'Erma di Bretschneider. (in Italian)

Krähling, J., Halmos, B., Fekete, J. Cs. (2006) A fertődi Marionettszínház új értelmezése - Az épületkutatás ("Bauforschung") és az alakhű felmérés, mint kutatási módszer alkalmazásával. Épités- Épitészettudomány. 34 (1). pp. 5-55. DOI: 10.1556/eptud.34.2006.1-2.1 (in Hungarian)

Oursel, A.-M. (1969) Fiche de repérage: Chiddes, Eglise Saint-Etienne, annexe de Pressy-sous-Dondin, Archives départementales de Saône-et-Loire. 5 FI 128/1. (in French)

Rameau, B. (1899) La Révolution dans l'ancien diocèse de Mâcon. Annales de l'Académie de Mâcon. Tome IV. (in French)

Reiche, J. (2002) Architektur und Bauplastik im Burgund um 1100. Die Kirchen von Gourdon und Mont-Saint-Vincent. Bonn, Phil. Diss. Petersberg: Michael Imhof Verlag. (in German)

Virey, J. (1934) Les église romanes de l'ancien diocése de Mâcon, Cluny et sa région, Mâcon, Protat.

Visites pastorales de l'archiprêtré du Rousset, en 1746 (1913) Annales de l'Académie de Mâcon. Tome 13. (in French)

Fig. 10 Hypothetical periodization of the church of Chiddes, eastern façade

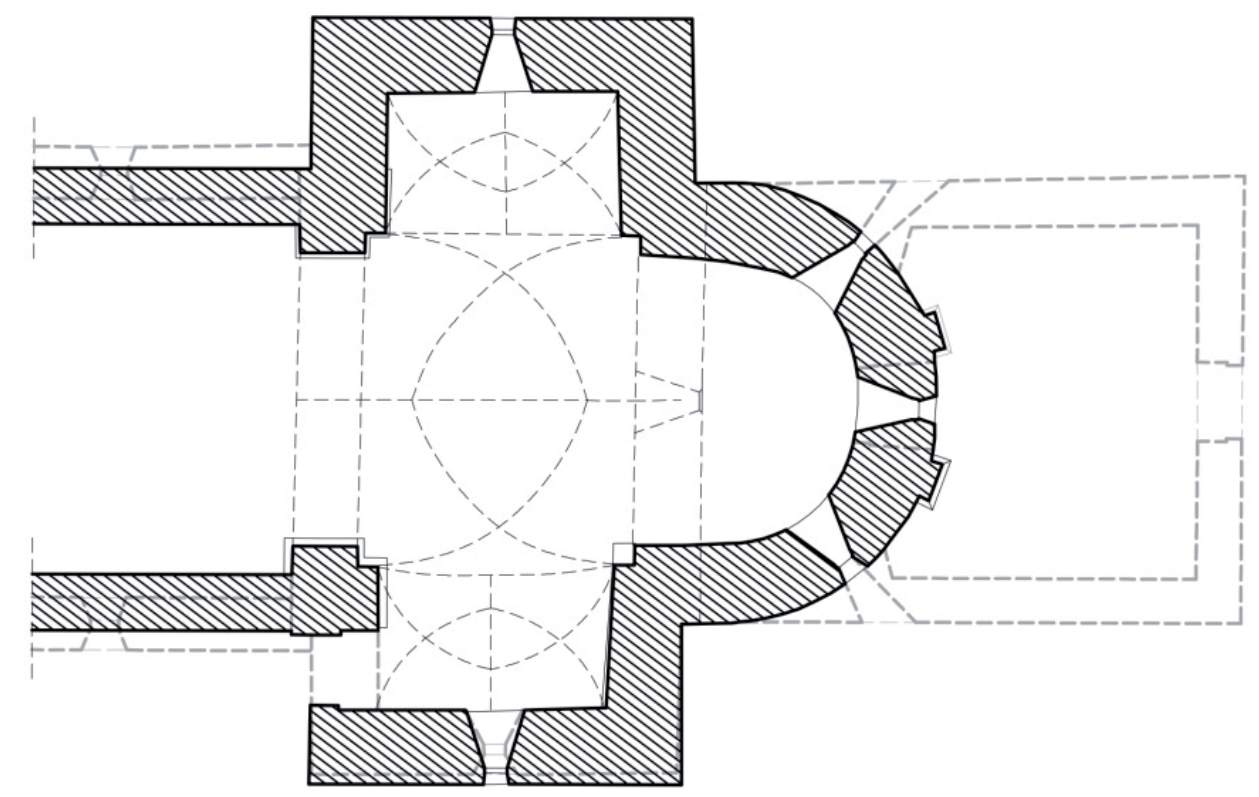

Fig. 11 The hypothetical reconstruction of the church's original plan compared to its present state 